\title{
PENGARUH KECEMASAN MATEMATIKA TERHADAP PEMAHAMAN KONSEP MATEMATIKA
}

\author{
Shinta Dwi Handayani \\ Program Studi Informatika, Universitas Indraprasta PGRI \\ Email: shintadh.1109@gmail.com
}

\begin{abstract}
Abstrak
Tujuan penelitian ini adalah untuk mengetahui pengaruh kecemasan matematika terhadap pemahaman konsep matematika. Metode yang digunakan adalah metode survey dan pengambilan sampel dengan teknik simple random sampling, sampel dalam penelitian ini sebanyak 90 siswa yang diambil dari 3 sekolah Swasta di Depok. Analisis dalam rangka pengujian hipotesis penelitian menggunakan uji analisis regresi linear, dengan hasil uji hipotesis menghasilkan terdapat pengaruh kecemasan matematika terhadap pemahaman konsep matematika.
\end{abstract}

Kata Kunci : Kecemasan, matematika, pemahaman konsep matematika

The purpose of this research is to know the influence of math anxiety towards the understanding of mathematical concepts. Method the used research is survey and sample methods with the technique of simple random sampling, the sample in this study as 90 students. Analysis research to hypothesis testing using linear regression analysis test, with the results of a test of hypothesis generating, there is the influence of mathematics anxiety towards the understanding of mathematical concepts.

Key Words : Anxiety, mathematics, understanding of math concepts

\section{PENDAHULUAN}

Matematika adalah salah satu pelajaran wajib pada jenjang pendidikan formal. Ini dapat dilihat dari pelajaran matematika yang menjadi salah satu syarat kelulusan siswa untuk pendidikannya di sekolah. Bagi siswa belajar matematika di sekolah adalah hal yang sudah biasa mereka pelajari, karena pelajaran matematika sudah dipelajari siswa dari sekolah dasar hingga sekolah menengah. Namun pertanyaannya adalah, apakah pelajaran matematika yang merupakan syarat kelulusan dan pelajaran yang sering dipelajari di sekolah akan membuat siswa senang untuk belajar matematika, hampir dari sebagian siswa jawabannya adalah tidak, karena dalam kenyataannya pelajaran matematika adalah pelajaran yang dihindari oleh siswa walaupun menurut mereka pelajaran matematika adalah pelajaran yang penting untuk kelulusannya. Hal ini sesuai dengan penelitian [1], hasil penelitian menemukan bahwa sebanyak $45 \%$ mempersepsikan matematika cukup sulit, dan sebanyak $80 \%$ mengatakan matematika merupakan pelajaran yang penting. Banyak dari siswa yang beranggapan bahwa pelajaran matematika adalah pelajaran yang menyulitkan, terlalu banyak rumus, dan tidak relevan pada kehidupannya. Sangat disayangkan jika matematika selalu dijadikan pelajaran yang menyulitkan dan membosankan, terlebih matematika selalu dijadikan pelajaran yang dihindari hanya karena pemikiran awal yang salah. Melihat fenomena ini tidak heran jika nilai pelajaran matematika ataupun pemahaman konsep matematika siswa di sekolah kurang memuaskan.

Pemahaman adalah suatu proses yang terdiri dari kemampuan untuk menerangkan dan menginterpretasikan sesuatu, mampu memberikan gambaran, contoh dan penjelasan yang lebih luas dan memadai serta mampu memberikan uraian dan penjelasan yang lebih kreatif, sedangkan konsep merupakan sesuatu yang 
tergambar dalam pikiran, suatu pemikiran, gagasan, atau suatu pengertian. Sehingga siswa dikatakan memiliki kemampuan pemahaman konsep matematika jika siswa dapat merumuskan strategi penyelesaian, penerapan perhitungan sederhana, menggunakan simbol untuk mempresentasikan konsep dan mengubah suatu bentuk ke bentuk lain [2].

Pemahaman konsep matematika sangat diperlukan oleh siswa untuk berhasil dalam belajar matematika, ini sejalan dengan [3], salah satu kunci keberhasilan dalam belajar matematika adalah penguasaan konsep. Perluya siswa dalam menguasai konsep matematika dikarenakan konsep matematika memiliki keterkaitan antara konsep satu dengan konsep lainnya. Jika siswa belum menguasai konsep dasar dalam memahami matematika maka tujuan pembelajaran yang diharapkan tidak akan tercapai dan siswa akan mengalami kesulitan dalam penyelesaian masalah matematika. Seperti dalam [4], pemahaman konsep-konsep yang terdapat dalam matematika sangat diperlukan untuk memahami matematika, konsep-konsep dasar pada matematika harus benar-benar dikuasai sejak awal sebelum mempelajari matematika lebih lanjut, dengan memahami konsep terlebih dahulu siswa akan lebih mudah menerima materi baru.

Dengan penguasaan pemahaman konsep diharapkan siswa mampu untuk mengembangkan pengetahuan yang didapatnya. Pemahaman adalah kemampuan seseorang untuk mengerti atau memahami sesuatu yang telah diperoleh atau dipelajarinya, kemudian sesuatu yang telah diperolehnya itu diingat dan dipahami sehingga mampu untuk dijelaskan kembali serta dapat mengembangkan pengetahuannya tersebut [5]. Pengertian ini dapat mengartikan bahwa bagaimana pemahaman konsep matematika sangat diperlukan siswa dalam belajar matematika, terlebih ketika siswa mendapatkan permasalahan matematika dalam mengerjakan soal. Ketika siswa mendapat kesulitan dalam mengerjakan soal diharapkan dengan kemampuan pemahaman konsep matematika yang baik siswa mampu mengingat dan mengembangkan konsep yang sudah ia terima sehingga dapat memecahkan masalah tersebut.

Kemampuan pemahaman konsep matematika setiap siswa berbeda. Banyak faktor yang mempengaruhi, salah satunya adalah kecemasan yang dialami siswa saat belajar matematika. Seperti dalam [6], kecemasan matematika adalah salah satu faktor yang mempengaruhi prestasi belajar matematika, faktor tersebut dapat dipengaruhi oleh beberapa hal, baik berkaitan dengan faktor intenal maupun faktor eksternal peserta didik. Kecemasan matematika merupakan kondisi yang takut dan khawatir terhadap pembelajaran matematika, kecemasan matematika muncul sebagai respon dari apa yang sedang dihadapi dalam pembelajaran matematika, kecemasan matematika dapat muncul karena dipicu oleh kemampuan siswa yang kurang dalam matematika, karakter guru matematika, model pembelajaran yang digunakan oleh guru, kesulitan matematika dan tidak percaya diri [7]. Kecemasan terhadap matematika sering terjadi dikalangan siswa dan bahkan menjadi penentu persepsi mereka terhadap pelajaran matematika.

Berdasarkan uraian di atas, maka permasalahan penelitian ini adalah: Adakah pengaruh kecemasan matematika terhadap pemahaman konsep matematika? Tujuan penelitian ini adalah untuk mengetahui pengaruh kecemasan matematika terhadap pemahaman konsep matematika. Dengan hipotesis penelitian Terdapat pengaruh kecemasan matematika terhadap pemahaman konsep matematika. 
Hasil dari penelitian ini diharapkan dapat menjadi referensi bagi guru dalam memahami siswa di kelas. Selanjutnya dapat digunakan sebagai referensi untuk penelitian lanjutan, dengan judul yang sama namun metode, model, teknik analisis, ataupun sampel yang berbeda, sehingga didapat sebuah temuan baru yang berguna untuk kemajuan ilmu pengetahuan, khususnya untuk memperbaiki kualitas pendidikan di Indonesia.

\section{METODE}

Penelitian ini merupakan penelitian survey, dimana peneliti menggambarkan fenomena yang terjadi berdasarkan data yang diambil dari responden menggunakan instrumen yang telah divalidasi sebelumnya. Penelitian ini dilakukan di 3 sekolah swasta yang berada di Depok pada tahun ajaran 2014/2015 yang terdiri dari: SMA Tugu Ibu Depok, SMA Putra Bangsa Depok, dan SMA Pribadi Depok. Jenjang pendidikan yang diteliti adalah Sekolah Menengah Atas kelas XI. Teknik sampling yang digunakan adalah simple random sampling. Jumlah anggota sampelnya adalah 90 siswa.

Data yang digunakan yaitu: instrument untuk mengukur Kecemasan Matematika (terbagi dalam indikator Respon Fisiologis, Respon Perilaku, Respon Kognitif dan Respon Afektif) dengan jumlah 36 butir pernyataan dan menggunakan skala likert 1-5, maka skor maksimum 180 dan skor minimum 36. Pemahaman Konsep Matematika (terbagi dalam indikator mendeskripsikan kaidah pencacahan, permutasi, dan kombinasi serta menghitung peluang suatu kejadian) dengan jumlah 10 butir soal esai.

Teknik analisis penelitian dalam rangka pengujian hipotesis menggunakan uji analisis regresi linier. Sebelum dilakukan pengujian hipotesis, terlebih dahulu dilakukan uji persyaratan analisis yang meliputi uji normalitas, uji linieritas, dan uji heteroskedasitisitas.

\section{HASIL DAN PEMBAHASAN}

Tabel 1. Deskripsi data tiap variabel

\begin{tabular}{|c|c|c|c|}
\hline & & $\begin{array}{l}\text { Kecemasan } \\
\text { Matematika }\end{array}$ & $\begin{array}{c}\text { Pemahaman } \\
\text { Konsep MTK }\end{array}$ \\
\hline$\overline{\mathrm{N}}$ & Valid & 90 & 90 \\
\hline & Missing & 0 & 0 \\
\hline & & 107.09 & 56.94 \\
\hline & & 108.00 & 60.00 \\
\hline & & 80 & 60 \\
\hline & eviation & 24.428 & 12.400 \\
\hline & & 86 & 50 \\
\hline & & 68 & 30 \\
\hline & num & 154 & 80 \\
\hline
\end{tabular}

Dari hasil Tabel 1, pada variabel kecemasan didapat mean sebesar 107.09, ini dapat diartikan bahwa tingkat kecemasan responden berada pada tingkat sedang. Dimana untuk tingkat kecemasan dibagi menjadi 3 kategori, yaitu kecemasan pada tingkat ringan, sedang dan tinggi. Klasifikasi kecemasan tingkat ringan berada pada $36-84$, sedang pada $85-133$, dan tinggi pada $134-182$.

\section{Pengujian Persyaratan Analisis}

Sebagai syarat untuk melanjutkan analisis data, maka perlu dilakukan uji normalitas, uji linieritas, dan uji heteroskedastisitas.

Tabel 2. Hasil Uji Normalitas

\begin{tabular}{llrr}
\hline & & \multicolumn{2}{c}{ Kecemasan } \\
Matematika & Pemsep & MTK \\
\hline $\mathrm{N}$ & & 90 & 90 \\
Normal & Mean & 107.09 & 56.94 \\
Parameters $^{\mathrm{a}, \mathrm{b}}$ & Std. & 24.428 & 12.400 \\
& Deviation & & \\
Most & Absolute & .170 & .128 \\
Extreme & Positive & .092 & .128 \\
Differences & Negative & -.170 & -.122 \\
Test Statistic & & .170 & .128 \\
Asymp. Sig. (2-tailed) & $.133^{\mathrm{c}}$ & $.200^{\mathrm{c}, \mathrm{d}}$ \\
\hline
\end{tabular}

Dari Tabel 2, hasil perhitungan dengan menggunakan SPSS terlihat bahwa nilai 
signifikan secara keseluruhan $>0,05 \quad$ berdistribusi normal. sehingga dapat dikatakan bahwa data

Tabel 3. Hasil Uji Linieritas ANOVA Table

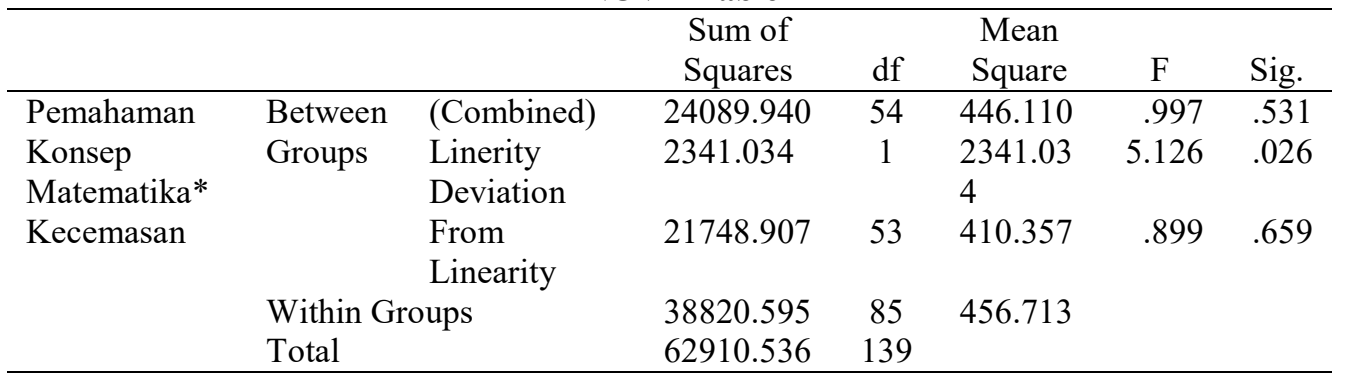

Dari Tabel 3, terlihat nilai pada kolom Sig baris deviation from linearity $=0,659>$ 0,05 . Dengan kata lain bahwa garis regresi hubungan kecemasan matematika dengan pemahaman konsep matematika adalah linier

Tabel 4. Hasil Uji Heteroskedastisitas Coefficients $^{\mathbf{a}}$

\begin{tabular}{lccccc}
\hline & \multicolumn{2}{c}{$\begin{array}{l}\text { Unstandardized } \\
\text { Coefficients }\end{array}$} & \multicolumn{2}{c}{$\begin{array}{c}\text { Standardized } \\
\text { Coefficients }\end{array}$} & \\
\cline { 2 - 5 } Model & $\mathrm{B}$ & $\begin{array}{l}\text { Std. } \\
\text { Error }\end{array}$ & Beta & $\mathrm{t}$ & \\
& & & & \\
\hline 1 (Constant) & 9.083 & 3.229 & & 2.813 & .006 \\
Kecemasan & .009 & 0.030 & .030 & .283 & .778 \\
\hline
\end{tabular}

Dari Tabel 4, terlihat nilai pada kolom Sig $=0,778$ lebih dari 0,05. Dengan kata lain bahwa tidak terjadi heteroskedastisitas dalam model regresi.

\section{Pengujian Hipotesis Penelitian}

Pengujian hipotesis dengan menggunakan uji analisis regresi sederhana. Dengan hipotesis penelitian:

Ho : Tidak terdapat pengaruh kecemasan matematika terhadap pemahaman konsep matematika

Ha : Terdapat pengaruh kecemasan matematika terhadap pemahaman konsep matematika

Kriteria uji:

Jika $t_{\text {hitung }}>\mathrm{t}_{\text {tabel }}$ : maka Ho ditolak artinya terdapat pengaruh kecemasan matematika terhadap pemahaman konsep matematika

Jika $t_{\text {hitung }}<t_{\text {tabel }}$ : maka Ho diterima artinya tidak terdapat pengaruh kecemasan matematika terhadap pemahaman konsep matematika

Tabel 5. Hasil Uji Analisis Regresi Coefficients $^{\mathrm{a}}$

\begin{tabular}{lrrrrr}
\hline \multirow{2}{*}{ Model } & \multicolumn{2}{c}{$\begin{array}{c}\text { Unstandardized } \\
\text { Coefficients }\end{array}$} & \multicolumn{2}{c}{$\begin{array}{c}\text { Standardized } \\
\text { Coefficients }\end{array}$} & \\
\cline { 2 - 5 } & B & $\begin{array}{l}\text { Std. } \\
\text { Error }\end{array}$ & Beta & T & Sig. \\
\cline { 2 - 5 } 1 (Constant) & 45.603 & 5.811 & & 7.847 & .000 \\
Kecemasan & .106 & .053 & .209 & 2.001 & .048 \\
\hline
\end{tabular}

Dari Tabel 5, didapat kan hasil persamaan regresi linier adalah $\mathrm{Y}=45,603+0,106 \mathrm{X}$. Persamaan regresi ini memberikan arti bahwa jika tidak ada kecemasan maka nilai konsisten pemahaman konsep matematika sebesar 45,603. Nilai koefisien pengaruh sebesar 0,106 ini mengartikan bahwa penambahan satu tingkat kecemasan maka pemahaman konsep matematika akan meningkat sebesar 0,106 .

Pengujian signifikan dari Tabel 5, terlihat bahwa sig. 0,048 dan $t_{\text {hitung }}=2,001$ sedangkan $t_{\text {tabel }}=1,663$. Karena nilai sig $<$ 0,05 dan $t_{\text {hitung }}>t_{\text {tabel }}$ maka Ho ditolak yang berarti terdapat pengaruh kecemasan matematika terhadap pemahaman konsep matematika. 
Tabel 6. Nilai $R$

Model Summary

\begin{tabular}{lcrrr}
\hline Model & $\mathrm{R}$ & R Square & $\begin{array}{r}\text { Adjusted } \\
\text { R Square }\end{array}$ & $\begin{array}{c}\text { Std. Error } \\
\text { of the } \\
\text { Estimate }\end{array}$ \\
\hline 1 & $.209^{\mathrm{a}}$ & .044 & .033 & 12.196 \\
\hline
\end{tabular}

Dari Tabel 6, diketahui nilai $\mathrm{R}$ square sebesar 0,044, yang berarti bahwa kecemasan matematika dapat mempengaruhi pemahaman konsep matematika sebesar 4,4\% sedangkan $95,6 \%$ dipengaruhi oleh faktor lain.

Hasil perhitungan dalam hipotesis memberikan hasil yang signifikan, hal ini membuktikan bahwa terdapat pengaruh kecemasan matematika terhadap pemahaman konsep matematika, hal ini sejalan dengan hasil penelitian [8], kecemasan siswa berpengaruh positif baik secara langsung maupun tidak langsung terhadap hasil belajar matematika. Dalam penelitian ini terlihat bahwa kecemasan dapat meningkatkan pemahaman konsep sebesar 0,106 walaupun dapat dikatakan bahwa pengaruh kecemasan terhadap peningkatan pemahaman konsep matematika terbilang rendah namun ini memberikan hasil positif, ini memberikan pemahaman bahwa setiap penambahan satu satuan atau satu tingkatan kecemasan akan berdampak pada meningkatnya kemampuan pemahaman konsep matematika.

Kecemasan tidak selamanya berpengaruh negatif karena pada dasarnya, semua manusia mempunyai perasaan cemas. Pada taraf yang sedang kecemasan dapat membuat seseorang lebih terpacu dalam menjalankan sesuatu. Seperti dalam [9], jika siswa tidak mengerti akan suatu materi pelajaran mereka akan cemas dan tidak akan ragu untuk berusaha lebih keras untuk memahami, tetapi kecemasan yang berlebihan juga berdampak buruk pada diri mereka karena dapat mengurangi efektivitas dari usaha yang mereka lakukan. Melihat ini betapa pentingnya kontrol siswa sangat diperlukan untuk mengontrol kecemasannya agar mendapatkan hasil yang positif, dan dalam penelitian ini kecemasan matematika yang dimiliki oleh siswa dalam kategori sedang sehingga kecemasan yang sedang ini memberikan motivasi siswa untuk lebih giat dalam belajarnya. Sikap atau motivasi untuk lebih giat dalam belajar ini dikarenakan adanya kecemasan jika akan mengalami kegagalan dalam belajar atau malu dengan teman-temannya jika tidak bisa mengerjakan soal yang diberikan oleh guru.

Dari kecemasan akan timbul motivasi pada siswa untuk belajar ataupun mengulas lagi pelajaran yang telah diberikan oleh guru, dengan seringnya siswa dalam mengulas pelajaran atau mencoba memahami suatu konsep matematika maka akan terbiasa juga siswa dengan konsep-konsep matematika, karena belajar matematika diperlukan kebiasaan dalam mengerjakan soal. Dengan siswa yang terbiasa dan paham akan konsep-konsep matematika maka akan berdampak pada meningkatnya pemahaman konsep matematika pada siswa. Kecemasan yang berpengaruh positif terhadap pemahaman konsep matematika ini juga harus dilandasi oleh kontrol yang baik pada diri siswa, agar kecemasan yang ditimbulkan dalam kategori sedang sehingga berdampak positif dalam kegiatan yang dilakukan siswa. Dan diharapkan guru mampu memahami siswanya di kelas dan membantu siswa dalam menghadapi kecemasan yang ada diri siswa.

\section{SIMPULAN}

Berdasarkan hasil penelitian dapat disimpulkan bahwa terdapat pengaruh kecemasan matematika terhadap pemahaman konsep matematika, ini dapat dilihat dari persamaan regresi linier, yaitu 
$\mathrm{Y}=45,603+0,106 \mathrm{X}$. Persamaan regresi ini memberikan arti bahwa jika tidak ada kecemasan maka nilai konsisten pemahaman konsep matematika sebesar 45,603 . Nilai koefisien pengaruh sebesar 0,106 ini mengartikan bahwa penambahan satu tingkat kecemasan maka pemahaman konsep matematika akan meningkat sebesar 0,106. Walaupun dapat dikatakan bahwa pengaruh kecemasan terhadap peningkatan pemahaman konsep matematika terbilang rendah namun ini memberikan hasil positif, ini memberikan pemahaman bahwa setiap penambahan satu satuan atau satu tingkatan kecemasan akan berdampak pada meningkatnya kemampuan pemahaman konsep matematika. Pengujian signifikan memberikan hasil sig. 0,048 dan thitung $=$ 2,001 sedangkan $t_{\text {tabel }}=1,663$. Karena nilai sig $<0,05$ dan $t_{\text {hitung }}>t_{\text {tabel }}$ maka Ho ditolak yang berarti terdapat pengaruh kecemasan matematika terhadap pemahaman konsep matematika. Dan pengaruh kecemasan terhadap pemahaman konsep matematika sebesar 4,4\% sedangkan $95,6 \%$ dipengaruhi oleh faktor lain. Siswa sebagai individu harus berusaha menghargai hidup dan kehidupannya, termasuk potensi yang dimilikinya sehingga kecemasan yang ada dalam dirinya akan berdampak positif.

\section{DAFTAR PUSTAKA}

[1] N. R. Siregar. "Persepsi Siswa Pada Pelajaran Matematika: Studi Pendahuluan Pada Siswa yang Menyenangi game". in Prosiding Temu Ilmiah X Ikatan Psikologi Perkembangan Indonesia, pp. 224232, 2017.

[2] I. W. Anita. "Pengaruh Kecemasan Matematika (Mathematics Anxiety) Terhadap Kemampuan Koneksi Matematis Siswa SMP”. Infin. J., vol. 3, no. 1, pp. 125-132, Feb. 2014.
[3] F. Fatqurhohman. "Pemahaman Konsep Matematika Siswa Dalam Menyelesaikan Masalah Bangun Datar". JIPM-Jurnal Ilmiah Pendidikan Matematika, vol. 4, no. 2, pp. 127-133, 2016.

[4] A. S. Sumaryati, D. U. Hasanah, and S. Negeri. "Upaya Meningkatkan Pemahaman Konsep Matematika Dengan Model Pembelajaran Inkuiri Terbimbing Siswa Kelas VIII C SMP Negeri 11 Yogyakarta”. $J$. Deriv., vol. 2, no. 2, pp. 56-64, 2015.

[5] H. Kusmanto et al., "Pengaruh Pemahaman Matematika Terhadap Kemampuan Koneksi Matematika Siswa Kelas VII Semester Genap SMP Negeri 2 Kasokandel Kabupaten Majalengka”. EDUMA: Mathemathics Education Learning And Teaching, vol.3, no.2, pp. 6175, 2014.

[6] F. S. Syafri. "Ada Apa Dengan Kecemasan Matematika?". J. Medives J. Math. Educ. IKIP Veteran Semarang, vol. 1, no. 1, pp. 59-65, 2017.

[7] H. P. Susanto. "Analisis Hubungan Kecemasan, Aktivitas, dan Motivasi Berprestasi Dengan Hasil Belajar Matematika Siswa". Beta J. Tadris Mat., vol. 9, no. 2, pp. 134-147, 2016.

[8] S. Djafar. "Pengaruh Kecemasan Belajar Matematika, Persepsi Siswa Tentang Keterampilan Mengajar Guru, Dan Iklim Kelas Terhadap Hasil Belajar Matematika Melalui Motivasi Belajar Pada Siswa Kelas VIII SMP Negeri Di Tana Toraja". Edumaspul - J. Pendidik., vol. 2, no. 1, pp. 11-23, Jan. 2018.

[9] A. B. Wicaksono dan M. Saufi. "Mengelola Kecemasan Siswa 
Dalam Pembelajaran Matematika". in Prosiding Seminar Nasional Matematika dan Pendidikan Matematika FMIPA UNY, pp. 8994, 2013. 